\title{
Sodium hypochlorite for sarcotesta remotion from papaya seeds: anatomical studies ${ }^{1}$
}

\author{
Valquíria Aparecida Mendes de Jesus $2^{*}$, Eduardo Fontes Araújo ${ }^{3}$, Fábio Lúcio \\ Santos $^{4}$, Eduardo Alves ${ }^{5}$, Luiz Antônio dos Santos Dias ${ }^{3}$
}

\begin{abstract}
Although papaya world production is high, the integument of papaya seeds, called sarcotesta, is an obstacle in the seedling production process. The aim of this work was to develop techniques to facilitate the removal of papaya seed sarcotesta for seedlings production. For that, two assays were developed. For the first one, the seeds were immersed in different concentrations of active chlorine $(0,2,4,6$ and $8 \%$ ) at ratio 600:200 seeds/mL of solution, respectively, besides the study of intact seeds and seeds subjected to the sieve method + stagnant water. For the second one, the seeds were immersed in active chlorine $2 \%$ in different ratios (10:200; 200: 200; 400: 200 and 600: 200), and the concentration of $0 \%$ at ratio 10:200 and the sieve method + stagnant water. The effect of the treatments was evaluated by germination test and scanning electron microscopy. Sodium hypochlorite did not remove completely sarcotesta, but damaged it. In ratio 10:200 in a concentration of $2 \%$ of active chlorine for 24 hours, the embryo and the endosperm were not affected, resulting in $80 \%$ of germination, which can be an alternative to sarcotesta manual removal.
\end{abstract}

Index terms: Carica papaya L., anatomy, $\mathrm{NaOCl}$, scanning electron microscopy.

\section{Hipoclorito de sódio para retirada da sarcotesta de sementes de mamão: estudos anatômicos}

\begin{abstract}
RESUMO - Embora a produção mundial de mamão seja elevada, o tegumento das sementes, denominado sarcotesta, ainda representa um entrave no processo de produção de mudas. Este trabalho foi desenvolvido com o objetivo de viabilizar a retirada da sarcotesta de sementes de mamão visando a produção de mudas. Para tal, foram desenvolvidos dois ensaios. No primeiro, as sementes foram imersas em diferentes concentrações de cloro ativo $(0,2,4,6$ e 8\%) na proporção de 600:200, sementes $/ \mathrm{mL}$ de solução respectivamente, além do estudo de sementes intactas e sementes submetidas ao método da peneira + água parada. No segundo, as sementes foram imersas em cloro ativo a 2\% em diferentes proporções (10:200; 200:200; 400:200 e 600:200), além da concentração $0 \%$ na proporção 10:200 e o método da peneira + água parada. O efeito dos tratamentos foi avaliado pelo teste de germinação e por meio da microscopia eletrônica de varredura. O hipoclorito de sódio não removeu totalmente a sarcotesta, mas proveu danos à sua estrutura. Na proporção de 10:200 na concentração de $2 \%$ de cloro ativo por 24 horas, o endosperma e o embrião não foram afetados, resultando em uma germinação de $80 \%$, podendo ser uma alternativa à retirada manual da sarcotesta.
\end{abstract}

Termos para indexação: Carica papaya L., anatomia, $\mathrm{NaOCl}$, microscopia eletrônica de varredura.

\section{Introduction}

Carica papaya $\mathrm{L}$. is one of the most cultivated species in tropical and subtropical areas of the world, with world production of approximately 12 million tons per year (FAO - Food and Agriculture Organization of The United Nations, 2014). The properties of the substances present in papaya tree latex are

${ }^{1}$ Submitted on $09 / 01 / 2015$. Accepted for publication on 10/16/2015. ${ }^{2}$ Departamento de Agricultura, Universidade Federal de Lavras, Caixa Postal 3037, 37200-000 - Lavras, MG, Brasil.

${ }^{3}$ Departamento de Fitotecnia, Universidade Federal de Viçosa, 36570-000 Viçosa, MG, Brasil. of great interest in food industries such as meat tenderizing, besides the use in beers, cheeses, among others, as well as in pharmaceutical industries, where papain is used as a cardiac activator (Biazus et al., 2006).

The lack of knowledge about papaya seeds processing directly affects their production, resulting in high cost of the seeds and therefore high production cost, which increases the value

\footnotetext{
${ }^{4}$ Departamento de Engenharia, Universidade Federal de Lavras, Caixa Posta 3037, 37200-000 - Lavras, MG, Brasil.

${ }_{5}^{5}$ Departamento de Fitopatologia, Universidade Federal de Lavras, Caixa Postal 3037, 37200-000 - Lavras, MG, Brasil.

*Corresponding author < valquiriamj@yahoo.com.br>
} 
of the final product. Studies have shown that the presence of sarcotesta, also called exotesta, adversely affects the germination process of papaya seeds (Schmildt et al., 1993; Tokuhisa et al., 2007a; Tokuhisa et al., 2008; Melo and Seleguini, 2013).

Manual procedures to remove sarcotesta, employed in large companies in the papaya industry, besides being time consuming, are not feasible for a large number of seeds. The use of sodium hypochlorite may be an alternative to manual removal of sarcotesta and can also act on the esclerotest or part thereof, favoring the germination of freshly harvested seeds (Tokuhisa et al., 2007a). It has been recommended to degrade the endocarp in coffee beans at a concentration of $6 \%$ of active chlorine for 3 hours in seeds with initial moisture between 23 and 33\% (Sofiatti et al., 2008). Lima et al. (2012) have also reported the use of sodium hypochlorite as a viable alternative to replace the mechanical removal of the parchment in coffee beans, which causes damage to the embryo.

For papaya seeds, studies have shown that the elimination of sarcotesta by immersing the seeds in sodium hypochlorite solution at $0.5 \%$ for five hours promotes an increase in germination (Tokuhisa et al., 2007b).

Thus, this study has aimed to study the anatomy structures and germination of Golden variety papaya seeds subjected to sodium hypochlorite solution in different ratios and concentrations of active chlorine.

\section{Material and Methods}

Initially, the work was conducted at the Seed Research Laboratory at Federal University of Viçosa, where the samples were prepared and treatments applied. Then the samples were transported to the Laboratory of Electron Microscopy and Ultrastructural Analysis (LME) at Federal University of Lavras (UFLA), in waterproof containers and a controlled environment.

To obtain seeds, Golden variety fruits were used, belonging to the "Solo" group from the company Caliman Agrícola $\mathrm{S} / \mathrm{A}$, located in the Brazilian city of Linhares, ES. These were harvested at maturity stage one - up to $15 \%$ of the epicarp with yellow color - and were stored in a room with controlled temperature at $18^{\circ} \mathrm{C}$ for three days, at which time all the epicarp presented the yellow color. Fruits were cut in the longitudinal direction and the seeds were manually extracted. Later, the seeds were homogenized and selected for integrity, being subjected to two assays, broken down below.

Assay 1 - The seeds were immersed in a sodium hypochlorite solution in different active chlorine concentrations $(0,2,4,6$ and $8 \%$ ) for a period of 12 hours at a ratio of 600 seeds for $200 \mathrm{~mL}$ of solution $(0.3 \mathrm{~mL}$ per seed) and the anatomical images and germination of seeds subjected to different treatments were evaluated. Intact seeds (with sarcotesta) and seeds subjected to the sieve method were also evaluated, together for 24 hours in stagnant water.

Assay 2 - Seeds subjected to sodium hypochlorite solution containing $2 \%$ active chlorine for a period of 24 hours in the ratios among seeds (number) and volume $(\mathrm{mL})$ of the solution of 10:200, 200:200, 400:200 and 600:200, which is equivalent to $20,1,0.5$ and $0.3 \mathrm{~mL}$ of solution per seed, were evaluated by means of anatomical images and germination test. The best performing treatment for germination was compared to two other additional treatments (controls), being $0 \%$ of active chlorine for a period of 24 hours at a ratio of 10 seeds for 200 $\mathrm{mL}$ of water (without active chlorine) and sarcotesta withdrawal procedure by the sieve method, plus 24 hours in stagnant water.

The concentrations of active chlorine used in the assays were obtained by dilution of commercial sodium hypochlorite in distilled water. For immersion of intact seeds in the solution, they were distributed under metal screens, which were placed in gerbox-type boxes (clear plastic boxes measuring $10 \times 10$ $\mathrm{x} 4 \mathrm{~cm}$ ). The gerboxes containing the seeds were capped and taken to a B.O.D (Biochemical Oxygen Demand) germination chamber at a constant temperature of $25^{\circ} \mathrm{C}$ in the absence of light, where they remained for the periods for each treatment. After each treatment, the seeds were washed in running water for one minute to eliminate the hypochlorite solution.

The sieve method is traditionally used in companies producing papaya seeds and is based on the withdrawal of seeds from fruits and their storage in PVC (poly(vinyl chloride)) boxes containing a little water, for 24 hours, so that the fermentation process begins to occur. Afterwards, the seeds are placed on sieves and, under water jet, light pressure of the seeds on the sieve takes place to remove the sarcotesta.

Scanning electron microscopy: Initially, the samples were immersed in Karnovsky fixative solution for 24 hours. After fixation, they were transferred to a cryoprotectant liquid (30\% glycerol) for 30 minutes, and longitudinal and transverse cuts were done with a scalpel on a metal surface placed in a container containing liquid nitrogen. The cuts were placed in a container containing water and post-fixed in $1 \%$ osmium tetroxide for one hour. After this period, the cuts were washed three times in distilled water, then dehydrated in an increasing gradient of acetone $(25 \%, 50 \%, 75 \%, 90 \%$ once each and $100 \%$ three times) for 10 minutes each. Then, the material was subjected to a critical point drying apparatus (Blazers CPD 030) and the specimens were mounted on stubs with double sided carbon tape, placed on aluminum foil and coated with gold in an evaporator (Balzers SCD 050). The visualization of the samples and images was done on a LEO Evo 40 XVP scanning electron microscope at a working distance of $9 \mathrm{~mm}$. The 
counts and measurements were obtained using the computer program Leo User Interface (version Leo 3.2), available in a scanning electron microscope.

Germination test: It was performed according to the recommendations from Rules for Seed Testing (Brasil, 2009). Seeds were sown on germitest-type paper rolls, moistened with a water volume equivalent to 2.5 times the paper dry weight. The rolls were kept inside plastic bags in order to maintain moisture, in B.O.D. with alternating temperatures of 20 and $30{ }^{\circ} \mathrm{C}$, being 16 hours in the dark, and eight hours of exposure to light, respectively. Germination was evaluated by calculating the percentage of normal seedlings, being considered normal those that reached $2.5 \mathrm{~cm}$ and showed all complete and intact essential structures.

The experiments were conducted in a completely randomized design with four replications, where each repetition consisted of two determinations. The data were subjected to normality and homogeneity tests of variance and analysis of variance by the F-test at 5\% probability. For quantitative variables, which had a significant effect by the F-test, regression analyses were performed. The models were selected from the coefficient of determination and significance of the coefficients. The comparison of different treatments with additional treatments (controls) was performed by the Dunnett's test at 5\% probability. All analyses were performed using the R computer program.

\section{Results and Discussion}

Assay 1

The anatomical visualization allowed the observation of papaya seeds coats, i.e., testa and tegmen (Figure 1). The seeds of this group are bitegmic, as well as the seeds of the Formosa group of Formosa Roxo 45 and Sunrise Solo 45 genotypes, as found by Santos et al. (2009) in their studies of papaya seeds morphoanatomy.

Surrounding the endosperm, the following tissues that make up the integument were observed: tegmen, endotesta, mesotesta and exotesta, also called sarcotesta (Figures 1 and 2); the cells are parenchymatous in various forms in different tissues. According to Santos et al. (2009), sarcotesta, mesotesta and endotesta come from the outer integument and tegmen comes from the inner integument.

Sarcotesta has been suggested by various authors as responsible for limiting germination in papaya seeds (Schmildt et al., 1993; Tokuhisa et al., 2007a; Tokuhisa et al., 2008; Melo and Seleguini, 2013). Therefore, its removal is essential for germination to occur.

The effect of treatments on seed quality was evaluated by germination test at 30 days. Analyses results showed that there was a significant effect of the treatments in the $5 \%$ level of probability.

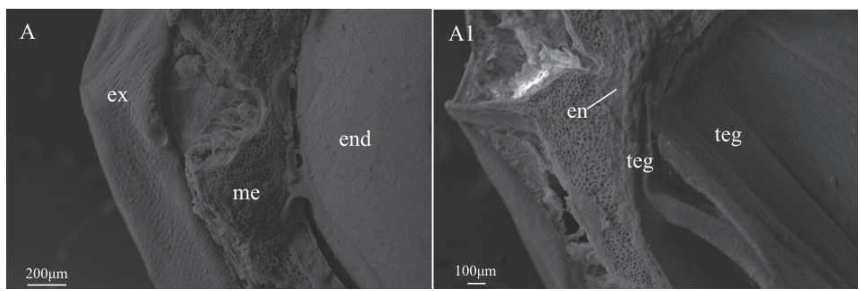

Figure 1. Image taken in a scanning electron microscope in Carica papaya L. seeds. A - Longitudinal section of the intact seed, highlighting the exotesta, mesotesta and endosperm, $150 \mathrm{x}$. A1 - Longitudinal section of an intact seed, highlighting the endotesta and tegmen, 150 x. Caption: en - endotesta, end - endosperm, ex exotesta, me - mesotesta, teg - tegmen.

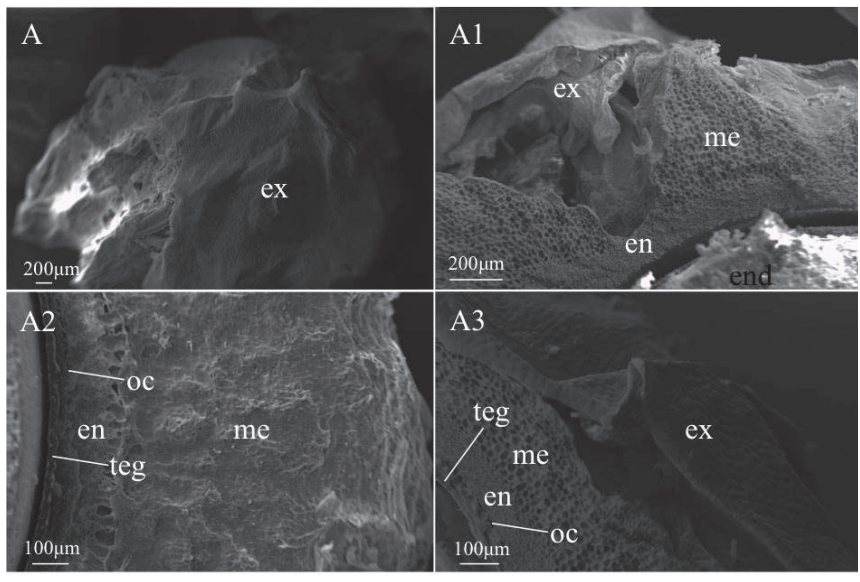

Figure 2. Image taken in a scanning electron microscope in Carica papaya L. seeds. A - Longitudinal section of an intact seed, highlighting the exotesta, 70 x. A1 - Longitudinal section of an intact seed, highlighting the exotesta, mesotesta, endotesta and endosperm, $200 \mathrm{x}$. A2 - Cross section of an intact seed, highlighting the mesotesta, endotesta, oxalate crystals and tegmen, $300 \mathrm{x}$. A3 - Longitudinal section of an intact seed, highlighting the exotesta, mesotesta, endotesta, oxalate crystals and tegmen, 300 x. Caption: oc - oxalate crystals, en - endotesta, ex - exotesta, me - mesotesta, teg - tegmen.

Equation 1 represents the model selected from the regression analysis. The model was chosen taking into account the coefficient of determination $\left(\mathrm{R}^{2}\right)$ and the significance of the regression coefficients.

Journal of Seed Science, v.37, n.4, p.228-235, 2015 


$$
\mathrm{Ge}=21.90+1.83 \mathrm{C}_{\mathrm{cl}} \quad R^{2}=0.81
$$

Where: $G e=$ germination, $\% ; C_{c l}=$ chlorine concentration, $\%$.

Figure 3 shows the germination behavior as a function of chlorine concentration, and it is observed that higher percentages of germination tend to occur at lower concentrations of active chlorine, tending to a decrease with increasing concentration.

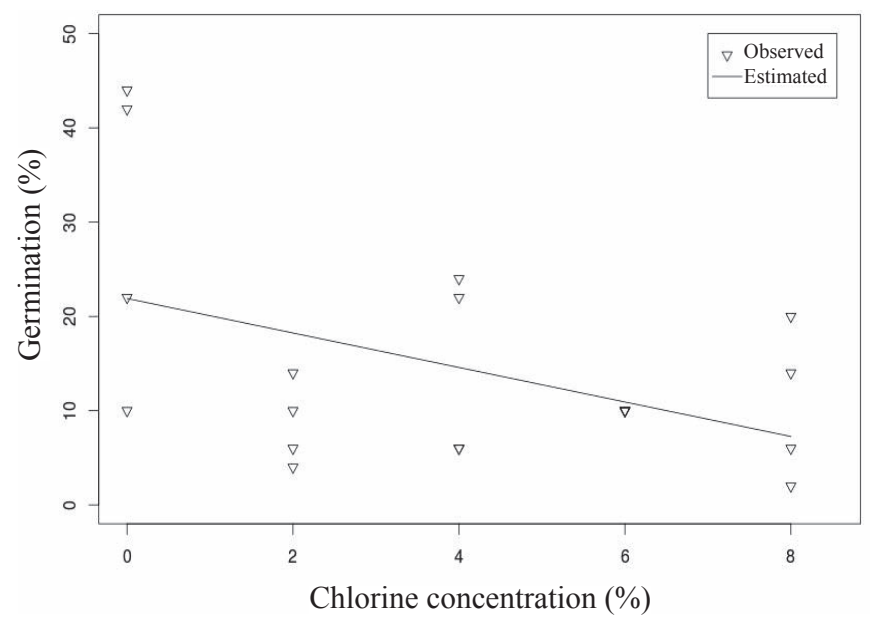

Figure 3. Germination at 30 days of papaya seeds due to the concentration of active chlorine for 12 hours.

At low concentration of active chlorine, germination tends to be larger, probably because, at this concentration, the amount does not impair parts that are essential for the germination process.

According to Meyer (1994), chlorine and its compounds are strong oxidizing agents and their use promotes both disinfection (destruction of pathogenic microorganisms), and oxidation (changing the structures of existing compounds by oxidation). As the oxidation reaction occurs, there is a consumption of chlorine and organic matter, which can lead to the elimination of sarcotesta. This reaction also occurs during fermentation. According to Alves et al. (2009), fermentation is a process commonly used in seeds in order to eliminate mucilage in several species. However, an intense oxidative process, due to the increased concentration of active chlorine for a period of 12 hours, may damage essential structures of the seed, thus jeopardizing germination.

Table 1 shows the germination results considering the seeds immersion in sodium hypochlorite $(\mathrm{NaOCl})$ at concentrations of $0,2,4,6$ and $8 \%$ of active chlorine, compared to further treatment (controls), intact seeds and removal procedure of sarcotesta by the sieve method plus 24 hours in stagnant water.
Table 1. Germination at 30 days of papaya seeds subjected to different treatments used in the first assay.

\begin{tabular}{lccc}
\hline Treatments & \multicolumn{3}{c}{ Germination (\%) } \\
\hline $0 \%$ of active chlorine & 29.50 & $\mathrm{~ns}$ & - \\
$2 \%$ of active chlorine & 8.50 & $\mathrm{~ns}$ & - \\
$4 \%$ of active chlorine & 14.50 & $\mathrm{~ns}$ & - \\
$6 \%$ of active chlorine & 10.00 & $\mathrm{~ns}$ & - \\
$8 \%$ of active chlorine & 10.50 & $\mathrm{~ns}$ & - \\
\hline Control & & & \\
\hline Intact seeds & & & \\
Sieve method +24.00 & \\
stagnant water & & \\
\hline- Significant and lower than the control in the column by the Dunnett's test at \\
the $5 \%$ level of probability. ns non significant when compared to the control \\
in the column.
\end{tabular}

The germination of $27 \%$ of intact seeds has not differed from the soaking treatments for 12 hours in solution with active chlorine in concentrations of 2, 4, 6 and $8 \%$, and it has not differed from the treatment of immersion in water in the absence of active chlorine for 12 hours. However, when comparing the soaking in water treatments in the absence of active chlorine and the ones in solutions with different concentrations to the sieve method plus 24 hours in stagnant water, the latter surpassed the others, presenting a total of $75.5 \%$ germination.

By scanning electron microscopy, it was possible to observe the sieve method efficiency plus 24 hours in stagnant water in the withdrawal of sarcotesta from papaya seeds, which was completely removed (Figures $4 \mathrm{C}$ and C1). As described above, this treatment has also stood out in germination, with the highest average (75.5\%) of germination (Table 1).

On the other hand, in treatments with the use of sodium hypochlorite at different concentrations, sarcotesta remained and showed small holes along the structure (Figures 4 D, E, $\mathrm{F}$ and $\mathrm{G}$ ). However, when analyzing intact seeds (Figure 4 A) and also the seeds subjected to treatment $0 \%$ of active chlorine for 12 hours of soaking (Figure 4 B), the presence of holes was also observed. Notwithstanding, by random counting performed in an area of $70,000 \mu \mathrm{m}^{2}$ of sarcotesta surface, there was an increase in the number of holes in seeds soaked in sodium hypochlorite compared to the intact ones (Figure $4 \mathrm{~A}$ ) and soaked in water at a concentration of $0 \%$ of active chlorine for 12 hours (Figure $4 \mathrm{~B}$ ). 


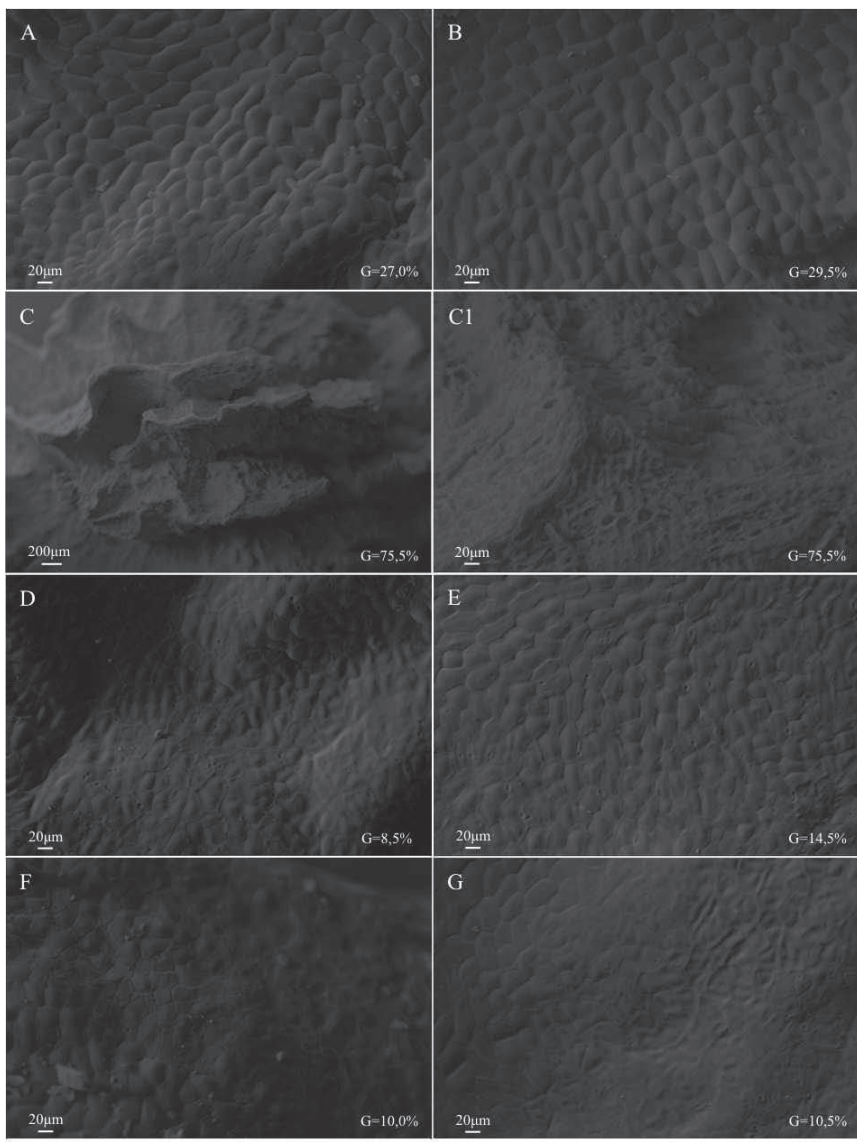

Figure 4. Image obtained using a scanning electron microscope in Carica papaya $\mathrm{L}$ seeds in paradermic sections. A - Intact seed, exotesta front view, 600 x. B - Treatment $0 \%$ of active chlorine for 12 hours, ratio 600:200, exotesta front view, $600 \mathrm{x}$. $\mathrm{C}$ and $\mathrm{C} 1$ - Sieve method treatment plus 24 hours in stagnant water, mesotesta front view, $80 \mathrm{x}$ and $600 \mathrm{x}$, respectively. D - Treatment $2 \%$ of active chlorine for 12 hours, ratio 600:200, exotesta front view, $600 \mathrm{x}$. E - Treatment $4 \%$ of active chlorine for 12 hours, ratio 600:200, exotesta front view, $600 \mathrm{x} . \mathrm{F}-$ Treatment $6 \%$ of active chlorine for 12 hours, ratio 600:200, exotesta front view, $600 \mathrm{x}$. $\mathrm{G}$ - Treatment $8 \%$ of active chlorine for 12 hours, ratio 600:200, exotesta front view, $600 \mathrm{x}$. Caption: $\mathrm{G}-$ Germination at 30 days of beginning sowing.

By analyzing the seeds anatomy from the obtained images, it is suggested that such damage in sarcotesta promotes the exchange of gases and liquids from the environment with the inside of seeds, favoring germination for papaya seeds. In the active chlorine mechanism of action there is a combination of chlorine with proteins, probably generating the formation of some compounds and modification of the structures (Donini et al., 2005). However, when analyzing the germination tests results, it was found that the intact seeds, as the one soaked in water at $0 \%$ of active chlorine for 12 hours (Figures 4A and B, respectively), which contained minor amounts of holes in the sarcotesta, had higher germination averages in relation to the treatments subjected to sodium hypochlorite, regardless of the concentration (Figures 4 D, E, F and G), although none of the treatments had been different from the control (Table 1). Probably, sodium hypochlorite was absorbed by the seeds affecting the embryo, thus resulting in smaller percentages of germination.

It was also observed that by increasing the concentration of active chlorine, there was more damage to sarcotesta, decreasing the boundary sharpness of the cells that make up the tissue (Figures $4 \mathrm{~F}$ and $\mathrm{G}$ ). It is believed that sodium hypochlorite can be carried out or facilitated by the disruption of cells, causing and/or increasing the fissures in the seeds. The active chlorine soaking probably affects the embryo, causing the treatments subjected to sodium hypochlorite to present low germination averages, ranging from 8.5 to $14.5 \%$ of normal seedlings.

Morphologically and anatomically, the endosperm was not affected by sodium hypochlorite, hence the embryo was also undamaged. Based on anatomical observations, sodium hypochlorite could be an alternative to manual withdrawal of sarcotesta, since the active chlorine damaged sarcotesta, causing or accentuating cracks in the seeds, without damaging the morphology and anatomy of the embryo. However, the germination test results showed that the seeds subjected to sodium hypochlorite had lower germination, probably due to some harmful chemical effect.

Assay 2

For a better analysis of the anatomical studies results, the germination test results in assay 2 were presented. The results of analysis of variance for germination at 30 days showed a significant difference at the $5 \%$ level of probability among the treatments averages.

Equation 2 represents the model selected from the regression analysis. The model was chosen taking into account the coefficient of determination $\left(\mathrm{R}^{2}\right)$ and the significance of the regression coefficients.

$$
\mathrm{Ge}=83.43-0.43 \mathrm{P}_{\mathrm{o}}+5.88 \times 10^{-4} \mathrm{P}_{\mathrm{o}}^{2} \quad R^{2}=0.98
$$

Where: $G e=$ germination, $\% ; P_{o}=$ ratio, number of seeds per $200 \mathrm{~mL}$ of solution.

Figure 5 shows the germination behavior related to the influence of the ratio (number of seeds per $200 \mathrm{~mL}$ of solution). It was observed that the germination percentage tends to decrease with increasing ratio until a minimum point; after this point, the percentage tends to increase. 
The higher germination rates occurred in ratios in which chlorine acted with higher intensity, i.e., in ratios with fewer seeds (Figure 5), until reaching a minimum point, which occurred with approximately 366 seeds per $200 \mathrm{~mL}$ of solution. However, by increasing the ratio after the minimum point there was an increase in germination, not following the trend that increasing the ratio would cause reduction in germination. This effect was probably not due to chlorine, but to some natural reaction such as fermentation, a consequence of increasing the number of seeds, degrading sarcotesta and inducing an increase in germination.

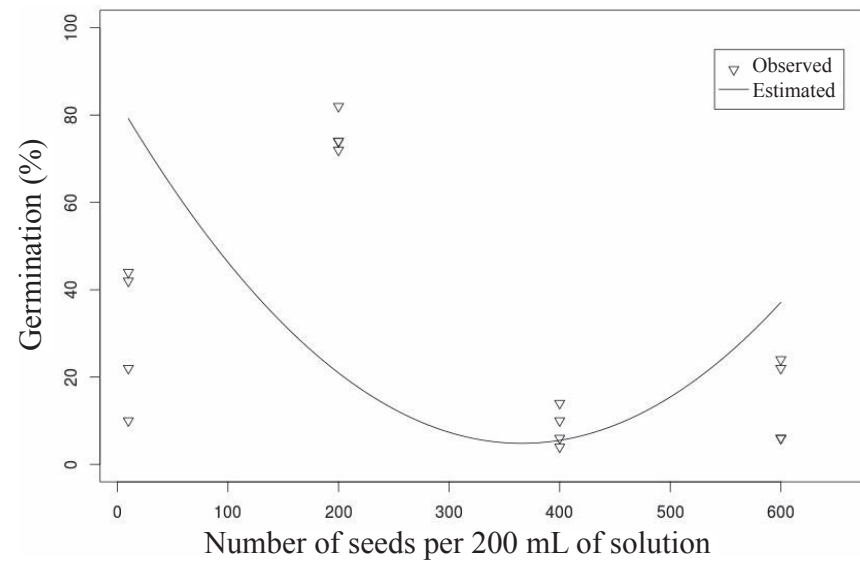

Figure 5. Germination at 30 days of papaya seeds due to the ratio between the number of seeds and the volume $(\mathrm{mL})$ of the sodium hypochlorite solution.

The treatment average of best performance ( $2 \%$ of active chlorine in the ratio 10:200) being $80 \%$, it was compared with the further treatments (controls), as shown in Table 2. When comparing this treatment and control, both in the same ratio, only differing in the presence and absence of chlorine in the solution, respectively, it is noted that the control treatment had an average of $10 \%$ germination, while the treatment of $2 \%$ in the ratio 10:200 had an average of $80 \%$. Thus, the beneficial effect of active chlorine at $2 \%$ for 24 hours of soaking for germination in the ratio of 10:200 is proven, reducing the need of labor for the preparation of papaya seeds. Treatment of 2\% at concentration 10:200 did not differ statistically from the sieve treatment (Table 2).

When analyzing the images, it can be seen, by the anatomy of the seeds, that in the ratio of 10:200 in the absence of active chlorine, the seeds did look close to normal (Figure $6 \mathrm{H}$ ), with all the integrity of structures, as described by Santos et al. (2009); however, seeds in the same ratio subjected to sodium hypochlorite with $2 \%$ of active chlorine for 24 hours remained with sarcotesta, but totally damaged (Figure 6 I). According to Resende et al. (2004), although chlorine is sparingly soluble, it reacts with water to produce hypochlorous acid $(\mathrm{HOCl})$ and keeping in solution hypochlorite ions $\left(\mathrm{OCl}^{-}\right)$, that are the oxidant active forms, which act on organic matter. These active forms cause denaturation of proteins, inhibition of enzymatic reactions and inactivation of nucleic acids in cells. This description is in accordance with Jaigobind et al. (2007), who describe hypochlorous acid as a powerful oxidizer, being capable of destroying cellular substances. In this case, there was dormancy breaking, increasing germination to $80 \%$.

Table 2. Germination at 30 days of papaya seeds subjected to the best treatment of the second assay (treatment I) and additional treatments (treatments $\mathrm{H}$ and $\mathrm{C}$ ).

\begin{tabular}{|c|c|c|c|}
\hline Best treatment of the second assay & \multicolumn{3}{|c|}{ Germination (\%) } \\
\hline $\begin{array}{l}\text { I }-2 \% \text { of active chlorine } \\
\text { in ratio } 10: 200\end{array}$ & 80.00 & + & ns \\
\hline \multicolumn{4}{|l|}{ Controls } \\
\hline $\begin{array}{l}\mathrm{H}-0 \% \text { of active chlorine } \\
\text { in ratio } 10: 200\end{array}$ & & 10.00 & \\
\hline $\begin{array}{l}\mathrm{C} \text { - Sieve method }+24 \text { hours } \\
\text { in stagnant water }\end{array}$ & & & 75.50 \\
\hline
\end{tabular}

+ Significant and higher than the control in the column by the Dunnett's test at the $5 \%$ level of probability.

ns non significant when compared to the control in the column.

Ratio: number of seeds per volume $(\mathrm{mL})$ of solution.

The damage observed in papaya seeds sarcotesta caused by active chlorine in the same conditions was smaller as the number of seeds was greater (Figures $6 \mathrm{I}, \mathrm{J}, \mathrm{K}$ and L). The results are as expected, since under the same conditions and the same volume of solution, there will more active chlorine available to act on a lower ratio of organic matter, that is, on a smaller number of seeds.

With the exception of the seeds in the absence of sodium hypochlorite, the other treatments showed cracks in sarcotesta. The cracks were irregularly present, in varied quantities and sizes, regardless of the studied ratio. These results show the action of sodium hypochlorite on the structure of papaya seeds. It is also noted that hypochlorite affected sarcotesta, mesotesta, endotesta and tegmen without morphological and anatomical damage to the endosperm and, therefore, the embryo, which indicates that sodium hypochlorite is an alternative to manual withdrawal of sarcotesta and a viable alternative to increase germination (unpublished images).

With the results obtained, sodium hypochlorite potential for replacing manual withdrawal of sarcotesta stands out, if it is associated to an appropriate ratio of seeds in relation to the volume of solution. Morphologically and anatomically, 
sodium hypochlorite was efficient to damage sarcotesta and other integument structures of papaya seeds without causing injury to the embryo which would impair germination.

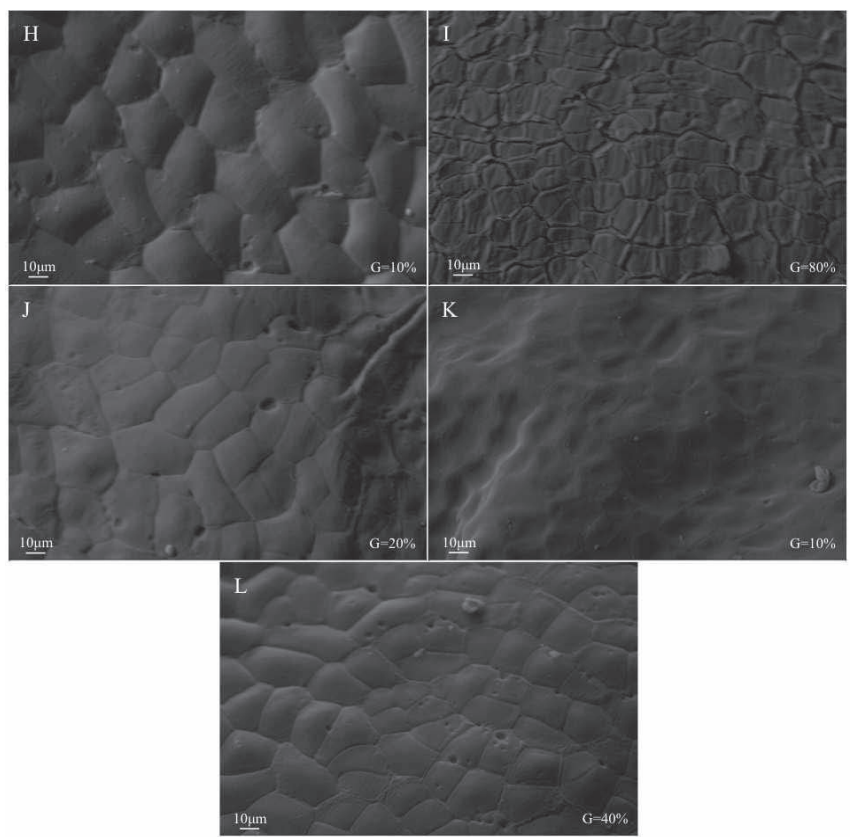

Figure 6. Image obtained using a scanning electron microscope in Carica papaya L seeds in paradermic sections. $\mathrm{H}$ - Treatment $0 \%$ of active chlorine for 24 hours, ratio 10:200, exotesta front view, $1500 \mathrm{x}$. I Treatment $2 \%$ of active chlorine for 24 hours, ratio 10:200, exotesta front view, $1500 \mathrm{x} . \mathrm{J}$ - Treatment $2 \%$ of active chlorine for 24 hours, ratio 200:200, exotesta front view, $1500 \mathrm{x}$. K - Treatment $2 \%$ of active chlorine for 24 hours, ratio 400:200, exotesta front view, $1500 \mathrm{x}$. L - Treatment $2 \%$ of active chlorine for 24 hours, ratio 600:200, exotesta front view, 1500 x. Caption: $\mathrm{G}-$ Germination at 30 days of beginning sowing.

\section{Conclusions}

The immersion of papaya seeds at the ratio of 10 seeds per $200 \mathrm{~mL}$ of sodium hypochlorite solution at a concentration of $2 \%$ of active chlorine for 24 hours promotes germination, as well as the sieve treatment plus 24 hours in stagnant water.

By anatomical observations, sodium hypochlorite does not affect the endosperm and consequently the embryo, and may be an alternative to manual removal of sarcotesta.

\section{Acknowledgments}

We thank CNPq (Conselho Nacional de Desenvolvimento Científico e Tecnológico) and FAPEMIG (Fundação de Amparo à Pesquisa do Estado de Minas Gerais) for granting financial support.

\section{References}

ALVES, E.U.; SILVA, K.B.; GONÇALVES, E.P.; CARDOSO, E.A.; ALVES, A.U. Germinação e vigor de sementes de Talisia esculenta (St. Hil) Radlk em função de diferentes períodos de fermentação. Semina: Ciências Agrárias, v.30, n.4, p.761-770, 2009. http://www.uel.br/revistas/uel/index. php/semagrarias/article/view/4071/3379

BIAZUS, J.P.M.; SANTANA, J.C.C.; SOUZA, R.R. Modelagem empírica do processo de biodegradação de efluentes protéicos por enzimas de Carica papaya sp. Revista Brasileira de Engenharia Agrícola e Ambiental, v.10, n.2 p.436-440, 2006. http://www.scielo.br/pdf/rbeaa/v10n2/v10n2a26.pdf

BRASIL. Ministério da Agricultura, Pecuária e Abastecimento. Regras para análise de sementes. Ministério da Agricultura, Pecuária e Abastecimento. Secretaria de Defesa Agropecuária. Brasília: MAPA/ACS, 2009. 395p. http:// www.agricultura.gov.br/arq editor/file/2946 regras analise sementes.pdf

DONINI, L.P.; FERREIRA-MOURA, I.; GUISSO, A.P.; SOUZA, J.A.; VIÉGAS, J. Preparo de lâminas foliares de aráceas ornamentais: desinfestação com diferentes concentrações de hipoclorito de sódio. Arquivos do Instituto Biológico, v.72, n.4, p.517-522, 2005. http://www.biologico.sp.gov.br/docs/ arq/v72 4/donini.PDF

FAO. Food and Agriculture Organization of the United Nations. http://www. fao.org.br. Accessed on: Aug, 6 ${ }^{\text {th }} 2014$.

JAIGOBIND, A.G.A.; AMARAL, L.; JAISINGH, S. Dossiê técnico: desinfetante doméstico. Instituto de tecnologia do Paraná, 2007. 22 p. http:// www.respostatecnica.org.br/dossie-tecnico/downloadsDT/MjY1

LIMA, J.S.; ARAUJO, E.F.; ARAUJO, R.F.; DIAS, L.A.S.; DIAS, D.C.F.S.; RENA, F.C. Uso da reidratação e do hipoclorito de sódio para acelerar a emergência de plântulas de cafeeiro. Revista Brasileira de Sementes, v.34, n.2, p. 327-333, 2012. http://www.scielo.br/pdf/rbs/v34n2/19.pdf

MELO, A.P.C.; SELEGUINI, A. Estádio de maturação de frutos e remoção física da sarcotesta na produção de mudas de mamão. Comunicata Scientiae, v.4, n.1, p.20-25, 2013. http://comunicata.ufpi.br/index.php/comunicata/ article/view/230/163

MEYER, S.T. O uso de cloro na desinfecção de águas, a formação de trihalometanos e os riscos potenciais à saúde pública. Cadernos de Saúde Pública, v.10, n.1, p.99-110, 1994. http://www.scielo.br/pdf/csp/v10n1/ v10n1a11.pdf

RESENDE, J.M.; FIORI, J.E.; SAGGIN JÚNIOR, O.J.; SILVA, E.M.R.; BOTREL, N. Processamento do palmito de pupunheira em agroindústria artesanal - uma atividade rentável e ecológica. Embrapa Agrobiologia, 2004. 54 p. http://sistemasdeproducao.cnptia.embrapa.br/FontesHTML/Pupunha/ PalmitoPupunheira/higiene.htm

SANTOS, S.A.; SILVA, R.F.; PEREIRA, M.G.; ALVES, E.; MACHADO, J.C.; BORÉM, F.M.; GUIMARÃES, R.M.; MARQUES, E.R. Estudos morfo-anatômicos de sementes de dois genótipos de mamão (Carica papaya L.). Revista Brasileira de Sementes, v.31, n.2, p. 116-122, 2009. http://www. scielo.br/pdf/rbs/v31n2/v31n2a13.pdf 
SCHMILDT, E.R.; FRONZA, V.; DIAZ, J.L.S.; UNÊDA, S.H.; ALVARENGA, E.M. Comparação de métodos físicos de remoção da sarcotesta e de métodos de secagem de mamoeiro (Carica papaya L.). Revista Brasileira de Sementes, v.15, n.2, p.147-151, 1993. http://www.abrates.org. br/revista/artigos/1993/v15n2/artigo01.pdf

SOFIATTI, V.; ARAUJO, E.F.; ARAUJO, R.F.; REIS, M.S.; SILVA, L.V.B.D.; CARGNIN, A. Uso do hipoclorito de sódio para degradação do endocarpo de sementes de cafeeiro com diferentes graus de umidade. Revista Brasileira de Sementes, v.30, n.1, p.150-160, 2008. http://www.scielo.br/pdf/ rbs/v30n1/a19v30n1.pdf

TOKUHISA, D.; DIAS, D.C.F.S.; ALVARENGA, E.M.; DIAS, L.A.S.; MARIN, S.L.D. Época de colheita dos frutos e ocorrência de dormência em sementes de mamão (Carica papaya L.). Revista Brasileira de Sementes, v.30, n.2, p.75-80, 2008. http://www.scielo.br/pdf/rbs/v30n2/a10v30n2.pdf
TOKUHISA, D.; DIAS, D.C.F.S.; ALVARENGA, E.M.; DIAS, L.A.S.; MARIN, S.L.D. Tratamentos para superação da dormência em sementes de mamão. Revista Brasileira de Sementes, v.29, n.1, p.131-139, 2007a. http:// www.scielo.br/pdf/rbs/v29n1/18.pdf

TOKUHISA, D.; DIAS, D.C.F.S.; ALVARENGA, E.M.; HILST, P.C.; DEMUNER, A.J. Compostos fenólicos inibidores da germinação em sementes de mamão (Carica papaya L.). Revista Brasileira de Sementes, v.29, n.3, p.161-168, 2007b. http://www.abrates.org.br/revista/artigos/2007/v29n3/ artigo22.pdf 